\title{
HUBUNGAN PENGETAHUAN, SIKAP, DAN TINDAKAN IBU RUMAH TANGGA TENTANG PRAKTIK PENCEGAHAN DEMAM BERDARAH DENGUE DENGAN RUMAH BEBAS JENTIK DI RW 05 KELURAHAN TANAH PATAH KOTA BENGKULU TAHUN 2012
}

\author{
Robed Nofryadi, Deri Karmelita \\ Poltekkes Bengkulu, Jurusan Kesehatan Lingkungan, Jl. Indragiri No.3 Bengkulu \\ Poltekkes Bengkulu, Jurusan Kesehatan Lingkungan, Jl. Indragiri No.3 Bengkulu, \\ Email : derikarmelita@gmail.com
}

\begin{abstract}
Highest dengue cases in 2010 in the city of Bengkulu occurred in Nusa Indah health center with a higher IR 166 per 100.000 and 2,94\% CFR. The housewife has a very important role in monitoring the presence of Aedes aegypti mosquito larvae in the home. The knowledge, attitude and positive action on the prevention of dengue by housewives, is expected to improve the status of the free larva. Formulation of research problem whether there is a relationship of knowledge, attitudes and actions the housewife on dengue prevention practices with free housing larva?. The purpose of research to know the relationship of knowledge, attitudes and actions the housewife on dengue prevention practices with free home larva. This type of research is a cross sectional analytic. Population 175 homes. Samples 122 homes. Sampling by proportional stratified sampling. Analysis conducted univariate and bivariate analyzes, usinf Chi Square test $\left(\chi^{2}\right)$. The results of univariate analysis that, as much as $62,30 \%$ knowledgeable good. $51,64 \%$ to be good housewives. $65,57 \%$ housewives to act less more free housing portion $72,13 \%$ larvae in the high category. There is a correlation between knowledge, attitudes and action the housewife on dengue prevention practices with free houses flick in RW 05 Tanah Patah Bengkulu in 2012 expected that the need for cross-sectional collaboration across programs that dengue preventioan efforts can be implemented with a well directed and programmed.
\end{abstract}

\begin{abstract}
Abstrak : Kasus DBD tertinggi tahun 2010 di Kota Bengkulu terjadi di wilayah Puskesmas Nusa Indah dengan Angka IR 166 per 100.000 jiwa dan CFR 2,94\%. Ibu rumah tangga mempunyai peran yang sangat penting dalam upaya memantau keberadaan jentik nyamuk Aedes aegypti di rumah. Adanya pengetahuan, sikap dan tindakan positif tentang pencegahan DBD oleh ibu rumah tangga, diharapkan dapat meningkatkan status rumah bebas jentik. Rumusan masalah penelitian apakah ada hubungan pengetahuan, sikap, dan tindakan ibu rumah tangga tentang praktik pencegahan demam berdarah dengue dengan perumahan bebas jentik?. Tujuan penelitian mengetahui hubungan pengetahuan, sikap, dan tindakan ibu rumah tangga tentang pratek pencegahan demam berdarah dengue dengan rumah bebas jentik. Jenis penelitian adalah analitik dengan rancangan cross sectional. Populasi 175 rumah. Sampel 122 rumah. Pengambilan sampel dengan cara proportional stratified sampling. Analisis yang dilakukan analisis univariat dan bivariat, dengan menggunakan uji Chi Square $\left(\mathrm{X}^{2}\right)$. Hasil penelitian dari analisis univariat bahwa, sebanyak 62,30\% ibu rumah berpengetahuan baik. 51,64\% ibu rumah tangga bersikap baik. $65,57 \%$ ibu rumah tangga dengan tindakan kurang Lebih sebagian $72,13 \%$ perumahan bebas jentik pada kategori tinggi. Ada hubungan pengetahuan, sikap dan tindakan ibu rumah tangga tentang praktik pencegahan DBD dengan rumah bebas jentik di RW 05 Kelurahan Tanah Patah Kota Bengkulu tahun 2012 Diharapkan perlu adanya kerjasama lintas sektoral lintas program agar upaya pencegahan penyakit DBD dapat dilaksanakan dengan terarah dan terprogram dengan baik.
\end{abstract}

Kata Kunci : Pengetahuan, Sikap, Tindakan, Perumahan Bebas Jentik DBD.

Nyamuk Aedes aegypti diperkirakan telah menginfeksi 100 juta kasus DBD terjadi di Nyamuk Aedes aegypti diperkirakan telah menginfeksi dunia setiap tahunnya, di Asia tenggara pada tahun 1997 tercatat 136.030 kematian karena DBD dengan angka CFR 0,76\% (WHO, 2005). Wabah DBD masih menjadi kendala masyarakat di berbagai daerah mengingat jumlah kematian begitu banyak terutama pada balita dan anakanak (Sungkar, 2007).

Penyakit Demam Berdarah Dengue (DBD) atau Dengue Hemorrhagic Fever (DHF) ialah penyakit yang disebabkan 
oleh virus Dengue yang ditularkan melalui gigitan nyamuk Aedes aegypti dan Aedes albopictus. Kedua jenis nyamuk ini terdapat hampir di seluruh pelosok Indonesia kecuali di tempat tempat ketinggian lebih dari $1000 \mathrm{~m}$ di atas permukaan air laut (Ginanjar, 2008). Virus dengue menginfeksi manusia dan beberapa spesies primata yang lebih rendah. Manusia merupakan reservoir utama virus di wilayah perkotaan. Virus dengue menginfeksi manusia dari satu orang ke orang lain oleh nyamuk Aedes dari subgenus Stegomyia. Aedes aegypti merupakan vector epidemic yang paling penting, sementara spesies lain seperti aedes albopictus, aedes polynesiensis, anggota kelompok Aedes Scutllaris dan Aedes (Finlaya) niveus juga dipustuskan sebagai vector sekunder. Semua sepesies tersebut, kecuali Aedes aegypti memiliki wilayah penyebaran sendiri, walaupun mereka merupakan vector yang sangat baik untuk virus dengue, epedemi yang ditimbulkan tidak separah yang diakibatkan oleh Aedes aegypti (WHO, 2004).

Demam Berdarah Dengue (DBD) merupakan salah satu penyakit menular yang dipengaruhi oleh faktor lingkungan dan faktor perilaku masyarakat. Faktor lingkungan antara lain karena kondisi geografis seperti tingkat ketinggian dari permukaan laut, peralihan musim yang berkepanjangan yang membuat jentik-jentik nyamuk Aedes aegypti semakin mudah untuk berkembang biak. Kondisi musim seperti angin, tingkat kelembaban udara, dan kondisi curah hujan menyebabkan timbulnya genangan-genangan air, serta kondisi kepadatan penduduk, mobilitas penduduk dan transportasi (Fathi, 2005).

Nyamuk Aedes aegypti meletakkan telurnya di tempat yang airnya jernih, setelah 2-3 hari telur tersebut menetas menjadi jentik. Jentik ini dalam waktu 6-7 hari berkembang menjadi kepompong kemudian dalam 1-2 hari berkembang menjadi nyamuk dewasa yang dapat menjadi vektor penyakit demam berdarah (Kusumaningrum, 2000).
Nyamuk Aedes aegypti kini telah bermutasi. Perubahan itu terjadi sebagai akibat dari perubahan iklim, pemanasan global, dan efek rumah kaca. Pola perilaku nyamuk berubah, perubahan itu dapat terlihat dari lokasi nyamuk berkembang biak. Tidak hanya itu, Jika biasanya nyamuk Aedes aegypti menyerang pada waktu pagi dan siang hari, nyamuk Aedes aegypti pun bisa menyerang pada malam hari, bahkan, di tempat terang sekali pun. Melihat kondisi tersebut, salah satu cara yang bisa dilakukan adalah memutus mata rantai perkembangbiakan nyamuk mulai dari telurnya sampai nyamuk dewasa. Program yang saat ini tengah digalakkan adalah pemberantasan sarang nyamuk (PSN). Penerapan pola $3 \mathrm{M}$, yakni menguras bak mandi, menutup tempat penampungan air dan mengubur barang bekas (Kemenkes RI P2B2, 2010).

Pada tahun 2009 total kasus DBD di Indonesia sebesar $0,02 \%$ dengan jumlah kematian 1,39\% (Kemenkes 2010). Sedangkan kasus DBD di Provinsi Bengkulu cendrung meningkat dari tahun-ketahun. Pada tahun 2010 dari 620 kasus DBD di Provinsi Bengkulu 352 kasus terjadi di Kota Bengkulu. Kejadian DBD di Kota Bengkulu mengalami peningkatan dari tahun ketahun. Kasus Meninggal pada tahun 2010 berjumlah 9 orang. Kasus DBD tertinggi tahun 2010 terjadi di wilayah Puskesmas Nusa Indah dengan Angka Incident Rate (IR) 166 per 100.000 jiwa dan Crude Frevalen Rate (CFR) 2,94\% (Dinkes Kota Bengkulu, 2011).

Puskesmas Nusa Indah terdiri dari 4 Kelurahan, Kelurahan Tanah Patah, kelurahan Nusa Indah, kelurahan Kebun Kenanga dan Kelurahan Kebun Beler. Angka kasus DBD tertinggi terjadi di Kelurahan Tanah Patah. Diketahuinya gambaran kejadian DBD di Puskesmas Nusa Indah Per Kelurahan dapat Kasus DBD tertinggi pada tahun 2010 terjadi di kelurahan Tanah Patah yaitu 14 kasus menderita positif DBD dan 1 orang meninggal. Pada tahun 2010, RW 05 merupakan daerah dengan kejadian kasus DBD tertinggi di Kelurahan 
Tanah Patah di mana CFR $(8,33 \%)$ dan IR $(14,925 / 1000$ penduduk). Upaya yang efektif dalam penanganan penyakit DBD adalah upaya preventif. Dalam upaya preventif melibatkan semua masyarakat. Masyarakat membutuhkan pengetahuan yang lengkap mengenai Penyakit Demam Berdarah Dengue meliputi penyebab, gejala penyakit dan penularannya sehingga dapat melakukan pencegahan sederhana di rumah masing-masing (Depkes RI, 2009). Ibu rumah tangga mempunyai peran yang sangat penting dalam upaya memantau keberadaan jentik nyamuk Aedes aegypti di rumah.

Berdasarkan Profil Dinkes Kota Bengkulu tahun 2010, survei rumah bebas jentik hanya dilakukan pada 7 wilayah puskemas dan tidak termasuk Puskesmas Nusah Indah, dimana rata-rata keseluruhan rumah bebas jentik pada 7 wilayah Puskesmas tersebut adalah 69,16\% (Dinkes Kota Bengkulu, 2011). Untuk keperluan penelitian maka peneliti melakukan survey awal untuk mengetahui Diketahuinya gambaran rumah bebas jentik di RW $05 \mathrm{Ke}$ lurahan Tanah Patah Kota Bengkulu pada tanggal 31 Januari 2012. Dengan hasil dari 8 rumah yang diperiksa, 5 rumah terdapat jentik nyamuk Aedes aegypti yang ditemukan pada pas bunga, kaleng bekas, ban mobil bekas dan bak mandi.

Pengetahuan masyarakat mengenai Demam Berdarah Dengue (DBD) merupakan langkah awal untuk menentukan tindakan pencegahan dan penanganan penyakit tersebut. Banyaknya kejadian luar biasa (KLB) penyakit DBD seringkali disebabkan minimnya pengetahuan masyarakat mengenai penyakit tersebut (Depkes RI, 2009). Pada bulan Juni tahun 2011 Dinas Kesehatan Kota Bengkulu telah melakukan penyuluhan pemberantasan penyakit DBD di RW 05 Kelurahan Tanah Patah Kota Bengkulu dengan sasaran kelompok ibuibu posyandu. Adanya pengetahuan, sikap dan tindakan positif tentang pencegahan DBD oleh ibu rumah tangga, diharapkan dapat membawa dampak terhadap perubahan perilaku dalam kegiatan PSN yang dianggap efektif dan efesien dalam memberantas vektor DBD atau yang lebih di kenal dengan 3M, dengan kegiatan tersebut dapat diharapkan akan meningkatkan status rumah bebas jentik.

Tujuan Penelitian adalah untuk mengetahui hubungan pengetahuan, sikap, dan tindakan ibu rumah tangga tentang praktek pencegahan demam berdarah dengue dengan rumah bebas jentik di RW 05 Kelurahan Tanah Patah Kota Bengkulu tahun 2012.

\section{BAHAN DAN CARA KERJA}

Jenis penelitian adalah observasi dengan rancangan cross sectional, dimana populasinya adalah jumlah rumah di Kelurahan Tanah Patah Kecamatan Ratu Agung Kota Bengkulu yang berjumlah 175 rumah di RW 05 Kelurahan Tanah Patah Kota Bengkulu. Pengambilan sampel dengan cara proportional stratified sampling dengan langkah-langkah sebagai berikut: menentukan jumlah RT, menentukan jumlah KK per RT dan menentukan jumlah sampel secara proportional di setiap RT sehingga berjumlah 122 rumah. Penelitian ini dilakukan di RW 05 Kelurahan Tanah Patah Kota Bengkulu pada 07 April Sampai dengan 10 Mei Tahun 2012. Pengumpulan data dilakukan dengan menggunakan data primer yaitu melalui kuesioner dan observasi menggunakan checklist pemeriksaan rumah ada atau tidak ada jentik, sedangkan data sekunder yaitu mengenai jumlah rumah dan ibu rumah tangga di RW 05 Kelurahan Tanah Patah Kota Bengkulu. Data dianalisis secara univariat dan bivariat dengan menggunakan uji chi square dengan tingkat kepercayaan $95 \%$ $(\alpha=0,05)$.

\section{HASIL}

\section{Analisis Univariat}

Analisis univariat dilakukan pada masing-masing variabel untuk menggambarkan distribusi frekuensi masing-masing variabel tersebut yaitu pengetahuan, sikap, 
tindakan responden tentang praktik pencegahan demam berdarah dengue dan perumahan bebas jentik di RW 05 Kelurahan
Tanah Patah Kecamatan Ratu Agung Kota Bengkulu Tahun 2012, dapat dilihat pada tabel berikut :

Tabel 1. Distribusi Frekuensi Pengetahuan, Sikap, Tindakan Responden Tentang Praktik Pencegahan Demam Berdarah Dengue dan Perumahan Bebas Jentik di RW 05 Kelurahan Tanah Patah Kecamatan Ratu Agung Kota Bengkulu Tahun 2012

\begin{tabular}{lcc}
\hline \multicolumn{1}{c}{ Variabel } & $\begin{array}{c}\text { Frekuensi } \\
(\mathbf{n = 1 2 2})\end{array}$ & Persentase (\%) \\
\hline Pengetahuan & & 37,70 \\
Kurang & 46 & 62,30 \\
Baik & 76 & 48,36 \\
Sikap & & 51,64 \\
Kurang & 59 & 65,57 \\
Baik & 63 & 34,43 \\
Tindakan & & 27,87 \\
Kurang & 80 & 72,13 \\
Baik & 42 & \\
Rerumahan Bebas Jentik & 34 & 88 \\
Tinggi & & \\
\hline
\end{tabular}

Tabel di atas dapat diketahui bahwa lebih dari sebagian $(62,30 \%)$ responden berpengetahuan baik, tentang pratik pencegahan DBD, lebih dari sebagian (51, $64 \%$ ) responden bersikap baik, dalam praktik pencegahan demam berdarah dengue, lebih dari sebagian $(65,57 \%)$ responden dengan tindakan kurang, dalam praktik pencegahan demam berdarah dengue dan lebih dari sebagian $(72,13 \%)$ perumahan bebas jentik pada kategori tinggi.

\section{Analisis Bivariat}

Analisis bivariat dilakukan untuk melihat hubungan antara variabel bebas dan terikat. Analisis bivariat dilakukan de-ngan uji chi square $\left(\mathrm{x}^{2}\right)$, dengan derajat ke-maknaan $(\alpha)$ 0,05 dan tingkat signifikan $95 \%$. Sedangkan untuk mengetahui besar faktor risiko digunakan uji Odd Ratio (OR). Berikut ini adalah hasil analisis data tersebut :

Tabel 2. Hubungan Pengetahuan, Sikap dan Tindakan dengan Rumah Bebas Jentik di RW 05 Kelurahan Tanah Patah Kecamatan Ratu Agung Kota Bengkulu Tahun 2012

\begin{tabular}{|c|c|c|c|c|c|c|c|c|}
\hline \multirow[t]{3}{*}{ Variabel } & \multicolumn{4}{|c|}{ Rumah Bebas Jentik } & \multirow{2}{*}{\multicolumn{2}{|c|}{ Total }} & \multirow{3}{*}{$p$} & \multirow{3}{*}{ OR } \\
\hline & \multicolumn{2}{|c|}{ Tinggi } & \multicolumn{2}{|c|}{ Rendah } & & & & \\
\hline & f & $\%$ & $\mathbf{f}$ & $\%$ & f & $\%$ & & \\
\hline \multicolumn{9}{|l|}{ Pengetahuan } \\
\hline Kurang & 41 & 0,001 & 5 & 10,87 & 46 & 100 & 10,615 & 5,060 \\
\hline Baik & 47 & 61,84 & 29 & 38,16 & 76 & 100 & & \\
\hline \multicolumn{9}{|l|}{ Sikap } \\
\hline Kurang & 50 & 0,002 & 9 & 15,25 & 59 & 100 & 0,002 & 3,655 \\
\hline Baik & 38 & 60,32 & 25 & 39,68 & 63 & 100 & & \\
\hline \multicolumn{9}{|l|}{ Tindakan } \\
\hline Kurang & 65 & 81,25 & 15 & 18,75 & 80 & 100 & 0,002 & 3,580 \\
\hline Baik & 23 & 54,76 & 19 & 45,24 & 42 & 100 & & \\
\hline
\end{tabular}

\section{Hubungan Pengetahuan dengan Rumah Be-} bas Jentik

Tabel di atas diketahui bahwa dari 46 responden berpengetahuan kurang, sebagian besar $(89,13 \%)$ rumah bebas jentik kategori tinggi dan 76 responden berpengetahuan baik, lebih dari sebagian (61,
$84 \%$ ) dengan rumah bebas jentik kategori tinggi. Hasil uji Chi-square $\left(\mathrm{x}^{2}\right)$ pada tabel tabulasi silang di atas didapat bahwa nilai $\rho=0,001<\alpha=0,05$, yang berarti ada hubungan pengetahuan ibu rumah tangga tentang praktik pencegahan Demam Berdarah Dengue dengan rumah bebas jentik di RW 
05 Kelurahan Tanah Patah Kecamatan Ratu Agung Kota Bengkulu Tahun 2012.

\section{Hubungan Sikap dengan Rumah Bebas Jen- tik}

Diketahui bahwa dari 59 responden bersikap kurang, sebagian besar $(84,75 \%)$ dengan rumah bebas jentik kategori tinggi dan dari 63 responden bersikap baik, lebih dari sebagian $(60,32 \%)$ dengan rumah bebas jentik kategori tinggi. Hasil uji Chisquare $\left(\mathrm{x}^{2}\right)$ pada tabel tabulasi silang di atas didapat bahwa nilai $\rho=0,002<\alpha=$ 0,05 , yang berarti ada hubungan sikap ibu rumah tangga tentang praktik pencegahan demam berdarah dengue dengan rumah bebas jentik di RW 05 Kelurahan Tanah Patah Kecamatan Ratu Agung Kota Bengkulu Tahun 2012.

\section{Hubungan Tindakan dengan Rumah Bebas Jentik}

Diketahui bahwa dari 80 responden dengan tindakan kurang, sebagaian besar $(81,25 \%)$ dengan rumah bebas jentik kategori tinggi dan 42 Responden dengan tindakan baik, lebih dari sebagian $(54,76 \%)$ dengan rumah bebas jentik kategori tinggi. Hasil uji Chi-square $\left(\mathrm{x}^{2}\right)$ pada tabel tabulasi silang di atas didapat bahwa nilai $\rho$ $=0,002<\alpha=0,05$, yang berati ada hubungan tindakan ibu rumah tangga tentang praktik pencegahan demam berdarah dengue dengan rumah bebas jentik di RW 05 Kelurahan Tanah Patah Kecamatan Ratu Agung Kota Bengkulu Tahun 2012.

\section{PEMBAHASAN}

\section{Hubungan Pengetahuan dengan Rumah Bebas Jentik}

Hasil analisis univariat pada tabel 2 . diketahui bahwa lebih dari sebagian $(62,30 \%)$ ibu rumah tangga berpengetahuan baik tentang praktik pencegahan DBD dan dari tabel 1. lebih dari sebagian $(72,13 \%)$ perumahan bebas jentik pada kategori tinggi. Pengetahuan ibu rumah tangga tentang penyakit DBD ini meliputi pemahaman masyarakat pada umumnya dalam hal cara penularan penyakit dan cara pemberantasannya.

Ibu rumah tangga harus mengetahui proses penularan DBD. Penularan DBD dimulai dari gigitan nyamuk Aedes aegypti. Setiap nyamuk pada setiap gigitan menyebabkan penularan. Adanya proses penularan dari penderita, melalui gigitan nyamuk, penyebaran virus DBD belum dimengerti dengan baik oleh masyarakat akan berdampak pada tindakan pencegahan yang kurang optimal, begitu pula mengenai konsep pemberantasan sarang nyamuk atau tempat perkembangbiakan.

Analisis bivariat menujukan nilai $\rho=$ $0,001<\alpha=0,05$, yang berarti ada hubungan pengetahuan ibu rumah tangga tentang praktik pencegahan Demam Berdarah Dengue dengan rumah bebas jentik di RW 05 Kelurahan Tanah Patah Kecamatan Ratu Agung Kota Bengkulu Tahun 2012. Nilai $\mathrm{OR}=5,060$ yang berarti responden berpengetahuan kurang memiliki risiko 5,060 kali terjadi rumah bebas jentik pada kategori rendah di banding reponden yang berpengetahuan baik. Penelitian ini sejalan dengan pendapat Depkes RI (2002), Jika warga masyarakat belum memahami tujuan, manfaat dan hubungan pencegahan nyamuk Aedes aegypti dengan kejadian Demam Berdarah Dengue maka tindakan mereka untuk melakukan PSN atau 3M akan kurang. Pada prinsipnya masyarakat perlu dibekali pengertian dan konsep kejadian penyakit yang benar, pemahaman dan keterlibatan masyarakat dalam pelaksanaan pemberantasan DBD sangat diperlukan. Program pemberantasan Aedes aegypti yang sukses dan berkesinambungan haruslah melibatkan kerja sama antara lembaga pemerintah yang terkait serta masyarakat.

Dengan pengetahuan yang baik tentang pencegahan penyakit DBD diharapkan timbul kesadaran untuk melaksanakan upaya pencegahan penyakit DBD. Penyakit 
DBD merupakan penyakit yang berbasis lingkungan. Setiap penyakit menular yang berbasis lingkungan maka upaya pencegahan yang efektif adalah melakukan pemutusan mata rantai penularan. Untuk melaksanakan upaya tersebut harus ada kesadaran yang ditimbulkan oleh pengetahuan yang baik (Depkes RI, 2002).

Notoatmodjo (2003), bahwa pengetahuan merupakan domain yang sangat penting untuk terbentuknya tindakan seseorang. Dari pengalaman dan penelitian terbukti bahwa perilaku yang didasari oleh pengetahuan akan lebih langgeng dari pada perilaku yang tidak didasari oleh pengetahuan, dan pengetahuan yang dimiliki oleh seseorang berkembang dengan tingkatan yang berbeda.

Pengetahuan yang dimiliki oleh ibu rumah tangga pada tahap awal hanya sebatas tahu yaitu mengingat tentang pencegahan penyakit DBD. Kemudian berkembang menjadi kemampuan memahami tujuan praktik pencegahan penyakit DBD, sehingga ibu rumah tangga mampu menerapkan pengetahuan dalam bentuk tindakan nyata yaitu melakukan praktik pencegahan penyakit DBD dengan baik dan benar. Ibu rumah tangga yang melakukan tindakan pencegahan penyakit DBD dengan baik berdasarkan pengetahuan yang baik tentang pencegahan penyakit DBD (Sungkar, 2007).

Hasil penelitian ini juga sejalan dengan buku petunjuk Depkes RI, 2005, tentang pencegahan penyakit DBD. Pengetahuan yang diperoleh oleh seseorang akan dapat membentuk perilaku seseorang yang dapat diwujudkan dalam bentuk tindakan. Upaya mempromosikan pencegahan dan pemberantasan DBD bertujuan untuk member pengetahuan pada masyarakat sehingga kesadaran masyarakat meningkat. Pengetahuan yang kurang akan membentuk perilaku pencegahan yang kurang dan begitupun sebaliknya. Angka bebas jentik (ABJ) adalah indikator keberhasilan gerakan PSN yang dilakukan oleh kelompok masyarakat yang tinggal dalam suatu lingkungan tertentu.
Penelitian ini sejalan dengan penelitian yang dilakukan oleh Arisandi (2010), ada hubungan yang signifikan antara pengetahuan kepala keluarga dengan pencegahan penyakit DBD Kelurahan Tanah Patah Kota Bengkulu.

\section{Hubungan Sikap dengan Rumah Bebas Jentik}

Analisis univariat pada tabel 2. (51, $64 \%$ ) ibu rumah tangga bersikap baik dalam praktik pencegahan demam berdarah dengue dan lebih dari sebagian $(72,13 \%)$ perumahan bebas jentik pada kategori tinggi. Sikap ibu rumah tangga tentang praktik pencegahan demam berdarah ini meliputi tanggapan persepsi ibu rumah tangga tentang pencegahan DBD.

Sikap merupakan kesiapan untuk bertindak, hampir sebagian $(48,36 \%)$ ibu rumah tangga bersikap kurang dalam praktik pencegahan demam berdarah, ini berarti hampir sebagian ibu rumah tangga di RW 05 Kelurahan Tanah Patah Kecamatan Ratu Agung Kota Bengkulu belum siap untuk melakukan tindakan pencegahan penyakit DBD, belum bisa menerima atau merespon faktor-faktor lingkungan yang memiliki potensi menyebabkan terjadinya penyakit DBD seperti sikap terhadap kaleng, ban bekas yang berserakan disekitar rumah, sikap terhadap pesan-pesan pemerintah yang disampaikan melalui media televise, majalah, poster dan baliho, sikap terhadap kegiatan M3. Sikap yang kurang tersebut menyebabkan tidak adanya rasa tanggung jawab terhadap pengendalian lingkungan dalam upaya pencegahan penyakit DBD.

Analisis bivariat menunjukan bahwa $\rho$ $=0,002<\alpha=0,05$. Ada hubungan sikap ibu rumah tangga tentang praktik pencegahan demam berdarah dengue dengan rumah bebas jentik di RW 05 Kelurahan Tanah Patah Kecamatan Ratu Agung Kota Bengkulu Tahun 2012. Nilai OR=3,655 responden bersikap kurang memiliki risiko 3,655 kali terjadi rumah bebas jentik pada kategori rendah di banding reponden yang bersikap baik. 
Penelitian ini sejalan dengan penelitian Rohadi (2009). Terdapat korelasi yang erat antara sikap dengan prilaku preventif DBD di wilyah RT 08 Desa Pasir Panjang Kecamatan Arut Selatan Pangkalan Bun.

\section{Hubungan Tindakan dengan Rumah Bebas Jentik}

Hasil analisis univariat diketahui bahwa lebih dari sebagian $(65,57 \%)$ ibu rumah tangga dengan tindakan kurang dalam praktik pencegahan demam berdarah dan lebih dari sebagian $(72,13 \%)$ perumahan bebas jentik pada kategori tinggi. Tindakan ibu rumah tangga tentang praktik pencegahan demam berdarah ini meliputi: melakukan tindakan kegiatan PSN, Apakah Ibu membersihkan bak mandi di rumah Ibu minimal sekali seminggu, mengubur kalengkaleng bekas, membersihkan tempat penampungan air di rumah seminggu sekali dan mengingatkan warga sekitar akan bahaya penyakit DBD.

Lebih dari sebagian ibu rumah tangga di RW 05 Kelurahan Tanah Patah Kecamatan Ratu Agung Kota Bengkulu belum melakukan tindakan praktik pencegahan BDB yaitu $(65,57 \%)$, angka tersebut masih sangat tinggi.

Persentase tindakan praktik pencegahan BDB tersebut dapat diartikan bah-wa:

1. $(65,57 \%)$, keluarga di RW05 Kelurahan Tanah Patah Kota Bengkulu tidak melaksanakan pemutusan mata rantai penularan penyakit DBD.

2. $(65,57 \%)$, Keluarga mempunyai potensi terjangkit penyakit DBD.

3. $(65,57 \%)$, rumah mempunyai potensi menjadi tempat perindukan nyamuk DBD.

4. Memperhitungkan jarak terbang nyamuk $100 \mathrm{~m} /$ hari dan luas wilayah RW $051,2 \mathrm{Km}^{2}$ maka seluruh penduduk di RW05 mempunyai resiko terjangkiti penyakit DBD.

Tabel 2. bahwa nilai $\rho=0,002<\alpha=$ 0,05 , yang berarti ada hubungan tindakan ibu rumah tangga tentang praktik pen- cegahan demam berdarah dengue dengan rumah bebas jentik di RW 05 Kelurahan Tanah Patah Kecamatan Ratu Agung Kota Bengkulu Tahun 2012. Nilai $\mathrm{OR}=3,580$ responden dengan tindakan kurang memiliki risiko 3,580 kali terjadi rumah bebas jentik pada kategori rendah di banding reponden dengan tindakan baik.

Sungkar (2007), prilaku penduduk merupakan faktor yang paling penting dalam upaya pemberantasan DBD selain peran tenaga kesehatan. Salah satu bentuk prilaku yang dimaksud disini adalah tindakan pencegahan penyakit DBD.

Keberadaan jentik nyamuk berkaitan erat dengan perilaku pencegahan penyakit DBD oleh masyarakat. Sedangkan partisipasi masyarakat dipengaruhi oleh kesadaran masyarakat akan bahaya penyakit DBD, yang dapat diwujudkan dengan melaksanakan gerakan kebersihan dan kesehatan lingkungan secara serentak dan gotong royong. Semakin besar komitmen pemerintah dan partisipasi masyarakat, maka semakin besar pula upaya pemberantasan DBD (Depkes RI, 2002).

Penelitian ini sejalan dengan penelitian Rohadi (2009). Terdapat korelasi yang erat antara tindakan dengan prilaku preventif terhadap DBD di wilyah RT 08 Desa Pasir panjang Kecamatan Arut Selatan Pangkalan Bun.

\section{KESIMPULAN}

Lebih dari sebagian $(62,30 \%)$ ibu rumah tangga di RW 05 Kelurahan Tanah Patah Kota Bengkulu berpengetahuan baik tentang praktik pencegahan DBD. Lebih dari sebagian $(51,64 \%)$ ibu rumah tangga di RW 05 Kelurahan Tanah Patah Kota Bengkulu bersikap baik dalam praktik pencegahan DBD. Lebih dari sebagian (65, $57 \%$ ) ibu rumah tangga di RW $05 \mathrm{Ke}-$ lurahan Tanah Patah Kota Bengkulu dengan tindakan kurang dalam praktik pencegahan DBD. Lebih dari sebagian (72, 13\%) perumahan bebas jentik di RW 05 Kelurahan Tanah Patah Kota Bengkulu pada kategori tinggi. Ada hubungan pengetahuan ibu rumah tangga tentang praktik 
pencegahan DBD dengan rumah bebas jentik di RW 05 Kelurahan Tanah Patah Kecamatan Ratu Agung Kota Bengkulu Tahun 2012. Ada hubungan sikap ibu rumah tangga tentang praktik pencegahan DBD dengan rumah bebas jentik di RW 05 Kelurahan tanah Patah Kecamatan Ratu Agung Kota Bengkulu Tahun 2012. Ada hubungan tindakan ibu rumah tangga tentang praktik pencegahan DBD dengan rumah bebas jentik di RW 05 Kelurahan tanah Patah Kecamatan Ratu Agung Kota Bengkulu Tahun 2012

Saran kepada peneliti lain : diharapkan hasil penelitian ini berguna sebagai bahan informasi untuk melakukan penelitian lebih lanjut tentang pencegahan DBD dengan Variabel-variabel lain yang belum

\section{DAFTAR KEPUSTAKAAN}

Arikunto, 2003. Metodelogi Penelitian. Renika Cipta. Jakarta

Bahang, 2009. Beberapa Cara Untuk Mencegah Penularan Penyakit Demam Berdarah Dengue. Diakses dari http://pedulidbd.com/ 2009/09/beberapa-cara-untukmencegahpenularan-penyakit-demam-berdarah-denguedbd-by-z-b-bahang-medicalentomologist.html tanggal 18 Desember 2011.

Chayati, 2006. Dinamika Aedes Aegypti Sebagai Vektor Penyakit. Jurnal Kesehatan KEMAS Volume 2 / No. 1 / Juli - Desember 2006

Depkes RI, 2002. Dirjen P2PL. Membina Gerakan PSN-DBD. Jakarta: Depkes RI Tahun 2002. , 2004. Kajian Masalah Kesehatan Demam Berdarah Dengue. Jakarta: Badan Penelitian Dan Pengembangan Kesehatan Depkes RI. 2005. Waspada Demam Berdarah. Jakarta: Depkes RI.

2005. Petunjuk Teknis Penyelidikan Epidemiologi, penanggulangan Seperlunya Dan Penyemprotan Massal Dalam pemberantasan penyakit Demam berdarah Dengue Departemen Kesehatan Republik Indonesia Direktorat Jenderal Pemberantasaan Penyakit Menular Dan Penyehatan lingkungan 1992 cetakan kedua tahun 2005. Depkes RI. Jakarta.

2009. Informasi Umum Demam Berdarah Pedoman Bagi Kader. Jakarta: Depkes RI.

Dinas Kesehatan Kota Bengkulu, 2011. Laporan Bidang P2PL (Pemberantasan Penyakit Dan Penyehatan Lingkungan) Tahun 2010. Bengkulu: Dinas kesehatan Kota Bengkulu.

Dinas Kesehatan Provinsi Bengkulu, 2010. Program P2 DBD Provinsi Bengkulu Tahun pernah diteliti. Bagi pendidikan, diharapkan Karya Tulis Ilmiah ini dapat menjadi bahan bacaan diperpustakaan Poltekes Kemenkes Bengkulu yang berhubungan dengan DBD. Bagi Petugas Puskesmas, Dinas Kesehatan dan Kantor Lurah perlu adanya komitmen dalam kerjasama pemberantasan penyakit DBD melalui kerja sama lintas program di puskesmas dalam upaya meningkatkan pengetahuan dan upaya pencegahan penyakit DBD oleh warga dan bagi masyarakat disarankan pada warga RW05 Kelurahan Tanah Patah Kecamatan Ratu Agung Kota Bengkulu untuk melakukan PSN, melaksanakan 3M seminggu sekali dan menggalakkan kegiatan gotong-royong yang bertemakan pemberantasan penyakit DBD.

2010, Seksi Penanggulangan Penyakit Dinas Kesehatan Provinsi Bengkulu. Bengkulu: Dinas kesehatan Provinsi Bengkulu.

Dinkes Kota Madiun, 2011. Jurnalberita.com 7 November 2011. 75 Persen Wilayah Kota Madiun Endemik DBD. Di akses dari http://DBD/Jurnal\%20DBD5.htm pada tanggal 25 Maret 2012.

Desti Arisandi, 2010. Hubungan Pengetahuan Kepala Keluarga Dengan Pencegahan Penyakit DBD di Kelurahan Tanah Patah Kecamatan Ratu Agung Kota Bengkulu Tahun 2010. Skripsi STIKes Tri Mandiri Sakti Bengkulu. Bengkulu.

Edei Suherman, 2007. Hubungan Pengetahuan dan Sikap Kepala Keluarga (KK) terhadap tindakan pencegahan penyakit Demam Berdarah Dengue (di Rw 22 Kelurahan Sungai Beliung Kota Pontianak) Tesis Universitas Indonesia. http://eprints.undip.ac.id/18490/1/3068.pdf tanggal 18 Desember 2011.

Eko Budiarto, 2004. Metodelogi Penelitian. Renika Cipta. Jakarta

Fatih, 2005. Peran fektor lingkungan dan perilaku terhadap penularan demam berdarahdengue di kota mataram. Jurnal kesehatan lingkungan, volome 2 Nomor 101, Juli2005 : 1 - 10 . Diases dari http//jurnal kesehatan lingkungan 21 juli 2012

Ginanjar, 2008. Demam Berdarah. Jakarta: PT. Bintang Pustaka.

Hadinegoro, Sri Rezeki, 2002. Demam Berdarah Dengue, Naskah lengkap Pelatihan Bagi Pelatih Dokter Spesialis Anak Dan Dokter Spesialis Penyakit Dalam. Dalam Tata 
Laksana Kasus DBD. Jakarta: Balai penerbit Fakultas Kedokteran Universitas Indonesia.

Kemenkes RI, 2010. Profil Kesehatan Indonesia Tahun 2009. Jakarta: Kemenkes RI.

Kusumaningrum, 2000. Prilaku Dan Siklus Hidup Nyamuk Aedes aegypty. Diakses dari http://garistepi.wordpress.com/2009/07/08/82 tanggal 01 Mei 2011.

Kemenkes RI P2B2, 2010. Mutasi Nyamuk Demam Berdarah. Diakses dari http://bataviase.co.id/node/130030 tanggal 18 Desember 2011 .

Sari, Maya 2009. Journal Kedokteran, Minggu 29 Maret 2009. Demam Berdarah Dengue (DBD) diakses dari http://journaldbd.- dbd.

Nadesul, 1996. Penyebab, Pencegahan, Dan Pengobatan Demam Berdarah. Jakarta: PT. Penebar Suwadaya.

Notoatmodjo, 2003. Pendidikan dan Perilaku Kesehatan. Jakarta: Rineka Cipta. 2007. Kesehatan Masyarakat Ilmu dan seni. Jakarta: Rineka Cipta 2010. Metodologi Penelitian Kesehatan. Jakarta: Rineka Cipta.

Puskesmas Nusa Indah, 2011. Laporan Program P2PL Puskesmas Nusa Indah Tahun 2010. Bengkulu: Puskesmas Nusa Indah.

Rohadi, 2009, Journal Kesehatan Lingkungan, 22 November 2009. Hubungan Pengetahuandan sikap dengan tindakan preventif terhadap demam berdarah dengue di wilyah RT 08 Desa Pasir panjjang Kecamatan Arut Selatan Pangkalan Bun. Oleh Rohadi. Di akses dari http:// Kesling.undip.ac.id. pada tanggal 24 Juni 2012.
Sudradjat SB, 2008. Demam Berdarah Dengue (DBD) Penyebab dan Perantara Penularan Manifestasi Penyakit Pencegahan dan Pengobatan. Diakses dari http://_purnamas.blogspot.com/2008/08/infodemam-berdarah.html tanggal 18 Desember 2011.

Sungkar, 2007. Pemberantasan Demam Berdarah Dengue: Sebuah Tantangan yang Harus Dijawab. Jakarta: Departemen Parasitologi, Fakultas Kedokteran Universitas Indonesia. Diakses dari http://www.google.co.id/search?q=upaya+pe mberantasan + DBD+ berbasis+Masyrakat \& tanggal 18 Desember 2011.

Teguh Widiyanto, 2007. Kajian Manajemen Lingkungan terhadap Kejadian Demam Berdarah Dengue (DBD) di Kota Purwokerto Jawa-Tengah Tesis. UGM

Suroso, 2000. Pencegahan dan Penanggulangan Penyakit Demam Dengue dan Demam Berdarah Dengue.Terjemahan, WHO dan Depkes RI, Jakarta.

Yunilda, 2009. Penentuan Deteksi Dini Sirotipe Virus Dengue Tipe-3 (Den-3), Dari Nyamuk

Aedes Aegpti Dengan Menggunakan Riverse Transkipase-PCR (RT-PCR), Diakses dari http://repository.usu.ac.id/ bitstream/123456789/6230/1/09E01494.pdf tanggal 3 Januari 2012.

World Heald Organization. 2004. Panduan Lengkap Pencegahan \&Pengendalian Dengue \& Demam Berdarah Dengue. Penerbit Buku Kedokteran EGC, Jakarta 